\section{TARget Losses in CASE OF A EURO BREAKUP}

\author{
HANS-WERNER SINN*
}

When exchange rate adjustments are impossible, imbalances of cross-border payment flows must be accommodated officially. This baseline fact about monetary union has sparked extensive discussion on what the resulting asset positions mean (Sinn 2011a and 2011b; Tornell and Westermann 2012; Whelan 2012).

On one side, Sinn and Wollmershäuser (2012) argue that Finland, the Netherlands, Luxembourg, and Germany face the risk of losing the Target claims of their national central banks should the euro break up. On the other, De Grauwe and Ji (2012) deny the existence of any such risk. They base this denial on the grounds that:

- The risk stems only from the self-elected net foreign asset position of these countries;

- Fiat money has a value independent of the corresponding national central bank's assets; and

- Foreign speculators could be excluded from a currency conversion if necessary.

Given that the eurozone's gross Target claims or liabilities currently amount to around 1 trillion euros and constitute the largest single item on the balance sheets of most of the central banks of the eurozone members, this would be good news for the four countries mentioned. If De Grauwe and Ji are right, however, one wonders, why Moody's recently announced that it is considering downgrading the credit rating of Germany, the Netherlands, and Luxembourg in view of the riskiness, among other factors, of their huge Target claims. ${ }^{1}$ Can it be that the analysts at Moody's have overlooked something?

\footnotetext{
* Ifo Institute. This paper was shown to Paul De Grauwe before pub-

lication. I am grateful for his reaction.
1 "Moody's Changes the Outlook to Negative on Germany,

Netherlands, Luxembourg and Affirms Finland's Aaa Stable Rating", http://www.moodys.com/research/Moodys-changes-theoutlook-to-negative-on-Germany-Netherlands-Luxembourg-PR_251214?lang=de\&cy $=$ ger.
}

This paper will show that they have not indeed overlooked anything, and that, in fact, all three of De Grauwe and Ji's central arguments are either erroneous or do not apply to the assessment of Target losses in the case of a eurozone breakup. To this end, let us consider the issue in greater detail. This paper begins by reviewing the nature of the Target imbalances according to Sinn and Wollmershäuser and then proceeds to deal with each of De Grauwe and Ji's counterarguments in turn. Some of the comments made here also apply to a new paper by Buiter and Rahbari (2012b) that came out after this reaction was written. In this paper I briefly refer to what I perceive as their error in the section on fiat money.

\section{How the Target balances came about}

Sinn and Wollmershäuser (2012) pointed out that by dramatically reducing the collateral requirements for the refinancing credits of eurozone central banks, the ECB undercut market rates in the Southern eurozone countries and Ireland. This enabled a huge asymmetric expansion of refinancing credit and money creation, compensating for stalling capital imports and outright capital flight. The monetary expansion in the Southern countries in turn enabled a net outflow of central bank money to other eurozone countries by way of international payment orders aimed at buying goods and assets and redeeming foreign debt. Sinn and Wollmershäuser (2012) demonstrated that this outflow represents a classical balance-of-payments imbalance, showed that its accumulated value is measured by the Target balances, and constructed the first comprehensive Target panel dataset out of the sometimes confusing and non-homogeneous balance sheet information provided by the eurozone member central banks and the IMF. ${ }^{2}$ They argued that the ECB compensated for, and may even have caused, capital flight inasmuch as it replaced expensive foreign interbank credit with cheaper credit from local electronic printing presses, and helped to maintain and prolong structural current account deficits that otherwise would have been difficult to finance.

\footnotetext{
2 Sinn and Wollmershäuser collected the first panel data set showing the Target balances of the eurozone countries.
}

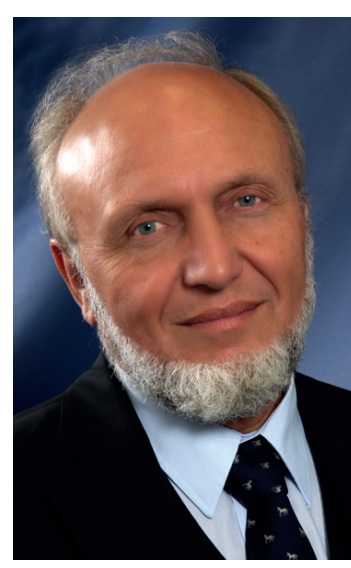


In the surplus countries, commercial banks placed the funds they withdrew from the deficit countries with their own central banks, which implied a sterilisation of the inflowing liquidity. Thanks to this sterilisation the policy has (to date) not been inflationary, but for that very same reason it is tantamount to a pure fiscal credit transfer that resembles the official intergovernmental credit transfers.

Sinn and Wollmershäuser (2012) argued that this policy was defensible at the time of the Lehman crisis, but has since begun to undermine the allocative function of the capital market by offering credit at conditions that do not take idiosyncratic country risks into account and undercut market rates. They also maintain that Target debts impose risks on the rest of the eurozone countries in proportion to their share in the ECB's capital, should the deficit countries default and leave the eurozone. Should the eurozone break up, the surplus countries' Target claims themselves would be at risk.

\section{Exogenous current-account balances?}

De Grauwe and Ji (2012) concentrate on the risk arising in case of a eurozone breakup. They argue that this risk stems from the size of the Northern countries' portfolio of net foreign assets built up from previous current-account surpluses, rather than from the composition of this portfolio. As the current-account surpluses are "entirely (their) ... own decision", independent of the ECB's refinancing policy and the resulting Target balances, there is no reason to worry about this risk.

This view is erroneous, since the current-account deficits, which resulted from years of easy access to international capital markets that the euro brought to the countries of southern Europe, could hardly have come down as slowly as they did during the crisis if the ECB had not replaced private capital inflows with cheap refinancing credit.

To be specific, a more restrictive ECB refinancing policy, in the sense of continuing to demand first-rate collateral from Southern banks rather than continuously reducing the collateral requirements to junk lev$\mathrm{els}^{3}$, would have resulted in a lower flow of refinancing credit to the banks of the deficit countries, lower Target liabilities, higher local interest rates in these

\footnotetext{
3 The Bundesbank President, Jens Weidmann, criticized the low collateral quality for the refinancing credits and the resulting Target credit in a letter to Mario Draghi (see Ruhkamp 2012).
}

countries, less capital flight or even continued private capital imports, less investment and government consumption, and hence lower current-account imbalances among the countries of the eurozone. Thus, whatever the value judgment on the ECB's policy is, it cannot be true that a country's current-account surplus and its net foreign asset position merely reflect that country's own decisions, as De Grauwe and Ji (2012) maintain.

Moreover, saying that the current-account deficits were sustained by the extra refinancing credit behind the Target balances does not equate to claiming that current-account deficits and Target deficits were positively correlated, as some economists criticising Sinn and Wollmershäuser (2012) have insinuated. On the contrary, to the extent that the ECB helped slow down the adjustment of pre-crisis current-account deficits despite the reversal of private capital flows, the correlation should have been small if not zero, while the correlation between private capital imports and Target deficits should have been (and was) strongly negative, as Sinn and Wollmershäuser (2012) demonstrated with their country analyses. However, it does mean that the ECB's extra refinancing credit, which resulted in Target debt, helped provide the funds needed to finance the current-account deficits. It is important to note that, by the definition of a country's budget constraint, the sum of Target balances, (private and intergovernmental) international capital flows and current-account imbalances is zero.

Even if De Grauwe and Ji's (2012) claim - that only the net foreign asset positions, and hence the accumulated current-account imbalances, matter for the breakup risk - was valid, the Target balances would still indicate such a risk. For without the public capital flow from North to South that these balances measure, the overall capital flow in this direction would have been smaller.

\section{Portfolio composition matters}

However, this is not the main problem with De Grauwe and Ji's (2012) analysis. The view that the portfolio composition of a country's net foreign asset position is largely irrelevant for an assessment of the breakup risk is in itself erroneous. If this view were correct, the risk of a balance sheet could be measured by the difference between its assets and liabilities, while the riskiness of the assets themselves would not matter. 
What the authors overlook is the difference in the risk that a eurozone breakup imposes on different kinds of foreign assets and on the different kinds of domestic owners of such assets. Consider a surplus country like the Netherlands. Dutch asset owners hold foreign ownership titles like bank debentures, government bonds, company shares, or titles to foreign real-estate property. If the euro breaks up, these titles continue to be legal titles protected by law. There is admittedly an exchange rate risk, but in principle the legality of the titles is not questioned. By contrast, the Dutch Target claims are claims on the ECB system held by a government institution, the Dutch central bank and hence the Netherlands, whose value hinges on the ECB's continued existence.

If the eurozone breaks up and the Target debtors go bankrupt, there is no clear legal basis for the Target claims, and the Netherlands would hold a claim against a system that no longer exists. Neither the ECB bylaws nor the Maastricht Treaty contain any rules for how this case would have to be handled. Should the euro break up, there would probably be a follow-up institution that would inherit the ECB's equity capital, which currently totals around 31 billion euros. The Netherlands would then have to compete for this equity with Germany, Finland and Luxembourg, who together with the Netherlands, hold Target claims currently amounting to about 1,000 billion euros. In all likelihood, the lion's share of the Target claims would be lost in such a scenario, while marketable ownership titles would remain legally valid. All four countries would then plead with their former partners in the eurozone to share in the losses, but the latter would probably point out that quite a number of official voices from the surplus countries had called the Target balances irrelevant, merely statistical items with no economic significance - and there would be enough economists defending this view, perhaps even alluding to the fiat money interpretation that will be discussed below.

Thus it is not irrelevant to Dutch risk that, by way of the ECB's generous refinancing policies that undercut market conditions, marketable claims have been converted into mere Target claims held by the Dutch central bank. Nothing could be more erroneous than such a view.

This is particularly true since a considerable part of the marketable assets constituting the Dutch net foreign asset position before the emergence of Target balances were claims against countries whose credit- worthiness was impeccable. It is well known, for example, that Dutch and German banks actively lent their funds to French banks, which then distributed them to southern European banks. Although France has a negative net foreign asset position, the Bank for International Settlements' statistics show that its banks had invested much more in the crisis-affected countries than Germany. During the crisis, the French banks partially retreated from the Southern countries with whose printing presses they could not compete; and the Dutch and German banks then partially retreated from France, since the French banking system no longer needed their funds. The Dutch and German banks instead placed their funds with their respective central banks or, equivalently, drew less refinancing credit from them. The double retreat of capital (from the South to France, and from France to the Netherlands and Germany) kept the French Target balances largely unchanged, but it generated Dutch and German Target claims and Southern Target liabilities. In the end, market-grade private claims on the French banking system in the Netherlands and Germany were replaced by additional private claims on the Dutch central bank and the Bundesbank, or by reduced liabilities from refinancing credit, with these national central banks themselves acquiring corresponding claims on the ECB system. This was certainly not a portfolio reallocation that kept the risk of a euro breakup unchanged for these countries as a whole, let alone for these countries' taxpayers.

\section{Target balances are not gold, and not even gold-backed securities}

The risk imposed by the Target balances can also be highlighted by comparing the eurozone with the Bretton Woods system of fixed exchange rates that lasted until 1973. That system also featured significant balance-of-payments imbalances that involved substantial cross-country currency flows, which were basically the same as the flow of Target claims today. However, any imbalances arising had to be settled in dollars or gold.

The balance-of-payments surpluses that countries like France or Germany held with the United States meant that dollars or dollar-denominated Treasury bills were accumulated by the Banque de France and the Bundesbank. As is well known, the Bretton Woods system came to an end when Charles de Gaulle asked the United States in 1968 to convert the 
dollars accumulated by the Banque de France into gold, because the United States did not have enough gold to convert the outstanding dollars of the whole world in this way (see Kohler 2011).

However, there were not only balance-of-payments imbalances with regard to the United States, but also among the European members of the Bretton Woods system. These imbalances had to be settled in dollars or gold, but given that the market price of gold was below the official dollar-gold parity, in practice settlements were made largely with gold (see also Neumann 1998).

The Bundesbank at the time accumulated 3,600 tonnes of gold, which, except for the 6 percent that was transferred to the ECB, is still in its possession and amounts to practically all the gold that the bank has. Gold nowadays has a value of about 19 times its price when the Bretton Woods system came to an end in 1973.

In the eurozone, the Bundesbank did not accumulate gold as a result of its balance-of-payments surplus, but instead has merely acquired Target claims; in other words claims that are backed by Target liabilities and the corresponding extra refinancing credits given to the commercial banks of the crisis countries, which currently earn an interest rate of 0.75 percent, which is far below the inflation rate. The central banks of Luxemburg, the Netherlands, and Finland are in a similar position.

For payments within the United States, the situation was similar to the Bretton Woods system or to true gold-standard systems until 1913. Balance-of-payments imbalances between commercial banks used to be settled with physical gold transfers, which, as we know from old Western movies, were not without risk. To facilitate settlement, the United States introduced the Federal Reserve System in 1914, consisting of 12 districts with their respective 'District Feds'. The advantage of that system was that the settlement was thereafter able to be made by simply transferring ownership of gold-backed securities in a federal clearing portfolio, without the gold having to be physically transported. Later, in the 1930s, the goldbacked securities were replaced with Federal Government bonds, but in principle the system still operates today. Since the transferred ownership shares bear an interest rate of 6 percent that is not socialised among the district Feds, there is quite a penalty for District Feds that create and lend out more than their fair share of the monetary base. This is the reason why a Target-like problem has never arisen in the United States to this day. ${ }^{4}$

In the United States, settlements are made every April according to a formula that typically eliminates some, but not all imbalances. During the crisis, the gross Interdistrict Settlement Account imbalances, the analogue of Europe's Target imbalances, increased to a maximum of 2.9 percent of US GDP, but the settlement, as well as local reductions in money supply to raise interest rates that attract capital from other districts and thus help to avoid a settlement, have meanwhile reduced the gross claims to 0.6 percent of US GDP, or 96 billion US dollars (10 October 2012). By contrast, based on the Target figures for September 2012, gross Target claims amounted to 11.4 percent of the eurozone GDP, or 1,020 billion euros (see Sinn 2012b). Had the eurozone been set up like the Bretton Woods system or the US Federal Reserve system, these Target claims would have to be converted into gold-backed securities or safe marketable securities bearing a 6 percent rate of interest transferred from the debtor central banks to the surplus central banks. Taking the most recent figures available at the time of writing, the Bundesbank would then have received claims on assets (including 6 percent interest) worth 695 billion euros (September), the Nederlandsche Bank assets worth 125 billion euros (August), the Banque Centrale du Luxembourg assets worth 128 billion euros (July), the Suomen Pankki assets worth 60 billion euros (July), the Banque de France 12 billion euros (July), and the Eesti Pank 0.1 billion euros (July).

\section{Fiat money does not protect against Target losses}

To further demonstrate the irrelevance of Target balances, De Grauwe and Ji (2012) point to the nature of fiat money. They rightly argue that fiat money has a value in and of itself for the private agents using it; and that this value would not disappear if the euro ceases to exist and is replaced by a national currency.

Indeed, as fiat money is voluntarily held by private agents, even although it does not generate interest, it must be delivering liquidity services that are equivalent to the interest foregone by not converting it into interest-bearing assets, and the present value of these liquidity services is identical to the accounting value

\footnotetext{
${ }^{4}$ See Sinn (2012a); and Sinn and Wollmershäuser (2012, Figure 9).
} 
of the money itself. Thus, fiat money is real wealth, and the economic value of the liability side of a national central bank's balance sheet (for the private economy!) is independent of the value of the assets it holds, as the authors maintain. The central bank could destroy its assets without reducing the value of the monetary base, as the authors maintain.

While this is all true, it certainly does not mean that the central bank in question and the sovereign that owns it would not incur wealth losses if it destroyed its assets, as De Grauwe and Ji (2012) believe. ${ }^{5}$ After all, it is the assets bought with self-printed money and the interest flow they generate that create the seignorage wealth of a central bank. In the eurozone, the most important assets member central banks acquire are titles derived from providing refinancing credit to commercial banks, i.e. from lending them the newly printed money, and the value of these titles is equal to the present value of the interest flow from the commercial banks to the central banks that is generated by this credit. Voiding the central banks' claims on the commercial banks would eliminate this interest flow and would therefore make the central banks poorer.

Even although central banks have to book their outstanding monetary base as a liability, this base is equity from a truly economic perspective if the seignorage generated by the assets acquired with the newly created money is taken into account. ${ }^{6}$ It is even possible to reason that a central bank's right to increase its monetary base in the future and buy even more assets with newly printed money is unreported equity that increases the central bank's loss-bearing capacity, a view that follows from an early contribution by Wenger (1997) and was recently emphasised by Buiter and Rahbari (2012a and 2012b). ${ }^{7}$ However, all of this does not imply that destroying the assets would be harmless, since parts of the thus-defined economic equity itself would also be wiped out. It is surprising that this simple, but crucial point seems to have been overlooked by so many authors.

The central bank's assets stand for a flow of interest returns from commercial banks to the central bank, whose present value is the same as the value of the assets. Since the central bank's seignorage profit is

\footnotetext{
5 To cite the authors: "in the fiat money system we live in, the Bundesbank could destroy all its assets without any effect on the value of the money base - as long as people continued to trust the value of the money base - as long as people
Bundesbank to maintain price stability".

6 For a discussion of this in the context of the euro introduction see Sinn and Feist (1999).

7 See also Homburg (2012)
}

normally handed over to the sovereign, it is this sovereign and its domestic taxpayers who would suffer the loss if the Target claims, now the most important assets of four central banks in the eurozone, were destroyed.

In a normal situation without Target imbalances, as prevailed in the eurozone until 2007, the assets of a central bank consist predominantly of interest-bearing claims resulting from refinancing credit given to commercial banks within the country, or securities bought from them. The flow of seignorage profit thus comes largely from the domestic commercial banks and their credit customers, goes to the socialisation mechanism of the ECB, and is then distributed to the sovereigns, and hence taxpayers, of eurozone countries in proportion to their respective capital shares. In a symmetric equilibrium, every sovereign receives just as much seignorage profit as its central bank collects from the domestic commercial banks.

When the Target balances began to rise in the eurozone after the outbreak of the financial crisis in the summer of 2007, the electronic printing press was 'lent' by the Northern to the Southern central banks, and so the eurozone's claims from issuing refinancing credit and the corresponding interest revenue came increasingly from Southern rather than Northern commercial banks, the reallocation of claims being approximately measured by the Target balances (see Sinn and Wollmershäuser 2012). Due to the socialisation of seignorage in the ECB system, this is irrelevant for each central bank's distribution of seignorage to the respective sovereign as long as the euro exists. (There are severe disadvantages, however, for the capital-exporting countries insofar as the competition of the printing press keeps the market interest rates below the levels that otherwise would have prevailed.)

However, if the euro were to break up and if the Target claims were not to be honoured as legally valid titles, or the Target debtors were unable to repay while the Target-neutral countries objected to sharing in the losses, the seignorage stemming from the commercial banks of the Target debtor countries would no longer flow into a common pool and the Target surplus countries would lose their Target claims, with the present value of the lost seignorage being exactly equal to these claims (whatever the time path of the interest rate). This chain of events would be entirely independent of the fiat money aspect on which De Grauwe and Ji (2012) focus, and independent of the size of the 
ECB's or the Bundesbank's loss-bearing capacity emphasized by Buiter and Rahbari.

It also does not matter to whom the commercial banks lent the money they borrowed from their central banks, be they private clients or local governments, and whether or not the commercial banks were able to provide good collateral to their national central banks. The commercial banks, and not their clients, would be liable to pay the interest to their central banks, and if their central banks were not to honour their Target liabilities after a breakup of the eurozone, it would be the central banks of the Target-surplus countries that would suffer the loss. Given that the latter would lose their legal relationship with the commercial banks of the debtor countries, they would have to content themselves with the Target claims and incur a wealth loss equal to those claims, if the debtor countries' central banks did not honour the claims after a eurozone breakup. This would represent a real loss of interest returns from foreign commercial banks, regardless of the size of the loss-bearing capacity of the Target-surplus countries.

\section{Would restricting money conversion to residents avoid Target losses in case of a breakup?}

De Grauwe and Ji (2012) conclude their paper by arguing that the only risk for the 'virtuous German taxpayer' (and presumably for the equally virtuous Dutch and Finnish taxpayer) is a speculative flight into German deposits from countries whose currencies would the most likely devalue after a breakup. If the Bundesbank were to convert all domestic accounts into the new national currency, there would be too many deutschmarks to start with and hence one must reckon with inflation-induced wealth losses for the domestic economy. However, the Bundesbank could easily avoid this wealth loss by limiting conversion into the new national currency to residents.

This argument is true, but it applies only to lastminute capital flight. Since the speculative flight into German deposits generates new Target claims against the ECB system on the part of the Eurosystem that would not be recognised after a breakup of that system, the Bundesbank would indeed incur additional losses by carrying out the payment orders, filling German deposits on behalf of foreigners. There would be no difference between this case and the earlier capital flight already reflected in the Target balances.
However, the remedy the authors suggest, namely excluding non-residents from converting their German euro accounts into deutschmark accounts, only works for Target imbalances built up at the very last minute by transferring the money to German accounts. It would not help with the prior imbalances, because these did not result from the build-up of deposits in German banks.

For one thing, such deposits were at best transitory. Practically all of the money that foreigners transferred to Germany and that led to Target imbalances has quickly been converted into real assets, such as private and government bonds, or ownership titles to firms or real-estate. It would be impossible and illegal to disentangle the ownership claims generated in this way should the euro breakup.

More importantly, the capital flight reflected by the surge of Target imbalances in Ireland, Italy, and Spain was not predominantly the flight of capital owned by residents in these countries, but marked the retreat of banks in the surplus countries from the credit markets of the deficit countries, a flight from a stormy sea back to the home harbour. The banks of Luxembourg, the Netherlands, Finland, and Germany not only stopped lending to finance other countries' current-account deficits, but withdrew outstanding funds by refusing to renew credit contracts at maturity. The banks of the deficit countries also redeemed their debt in net terms because they found the credit from the domestic printing press cheaper than the interbank credit, given that the ECB did not demand a risk premium. The banks of the surplus countries invested the funds with their central banks instead, which received the Target claims. It would also be impossible to disentangle these operations if the euro were to break up. Thus, from the perspective of the deficit countries, the previous benefits from the Target imbalances in terms of a real resource flow would remain, but the corresponding debt would probably disappear.

\section{Conclusion}

Europe has suffered from a severe balance-of-payment crisis, as capital markets were no longer willing to finance current-account deficits and outright capital flight occurred, largely from Southern to Northern countries, prompting the ECB to step in with the printing press. By successively reducing the quality of the collateral that commercial banks had to pledge to 
their respective national central banks, the ECB dramatically expanded the monetary base created in the Southern countries of the eurozone by way of providing refinancing credit. This additional money replaced the money flowing out by way of payment orders to other countries for the purpose of buying goods and assets and for the redemption of foreign debt. Economists call this outflow a balance-of-payments deficit. The accumulated deficit is reported in the central bank balance sheets as Target debt, since it means that the central banks carrying out the payment order had to credit the payments to the private firms and banks receiving the payments.

Under the Bretton Woods system the balance-of-payments deficits between the European countries were largely settled with gold transfers between the central banks (since the market price of gold was below the dollar-gold parity). In the US Federal Reserve System, they are settled by transferring ownership shares of safe marketable assets in a federal clearing portfolio, the transferred capital bearing a rate of interest of 6 percent. In the eurozone they are simply booked as Target imbalances in the balance sheets of the central banks, and annually augmented by the main refinancing rate (currently 0.75 percent).

With its policy of offering generous refinancing conditions that undercut the capital market, the ECB did not cause, but sustained and slowed down the adjustment of the current-account imbalances stemming from the time when the euro triggered excessive capital flows to some of the periphery countries (implying a close-to-zero correlation between current accounts and Target balances). Without this policy, whether right or wrong, the deficits would have been difficult to finance, local interest rates would have been higher, and the imbalances would have been smaller.

The banks of the Northern countries used the excess liquidity coming in through payment orders from the South to redeem their stocks of ECB refinancing credit and to lend money to their central banks. Thus, the ECB's policy has effectively converted Northern savings from private marketable assets issued by other countries into claims on, or reduced debt with, the respective national central banks, which themselves hold corresponding Target claims on the ECB system. In many cases the conversion meant that Dutch and German claims against French banks, which retreated from their role as credit intermediaries between Northern and Southern Europe, were converted into Target claims on the ECB system.
It is a matter of debate whether the ECB has protected the eurozone from an irrational capital market, or distorted the allocation of capital in the eurozone and deprived the savers of the Northern countries of their interest income by undercutting market conditions. However, it definitely has tolerated, if not created, huge Target imbalances that impose a particular risk on the Northern countries should the euro break up. Thus, Moody's assessment of the risk that the Target balances impose on the Netherlands, Luxembourg and Germany is justified.

The Target claims represent a euro breakup risk for the creditor countries for the following reasons:

- Unlike the marketable assets behind a country's net foreign asset position, the Target claims would lose their legal base, because they are claims against a system that would no longer exist and because there are no legal rules and specifications in the ECB system to handle such a case. The equity capital of the ECB itself would only cover a tiny fraction of its Target liabilities.

- Although a country's monetary base would retain its value after a breakup of the euro and a conversion to national currency, it would not be irrelevant if a country's Target claims were to be destroyed, since they represent the present value of a flow of seignorage stemming from other countries' commercial banks that compensates for prior outflows of goods, assets, and debt certificates to these countries. An interruption of the flow of seignorage from foreign commercial banks would imply real wealth losses for the surplus country's taxpayers and/or savers, the present value of which equals the Target balances. This is entirely independent of the size of their loss-bearing capacity, which is irrelevant for the question in hand.

- If destroying the Target claims were irrelevant, then destroying the Bundesbank's stock of gold reserves would also be irrelevant, since this stock was accumulated from Target-like imbalances under the Bretton-Woods system.

- Excluding non-residents from a conversion of deposits into the new national currency is useful to counter a last minute surge in Target claims before a breakup, but it is no solution for the previously existing Target claims, given that the latter reflect prior purchases of goods and assets abroad, as well as a repayment of foreign debt. These transactions have left no traces in today's deposits. From a practical and legal perspective, it 
is impossible to identify the historical beneficiaries of the Target imbalances.

The risks described above, as well as the implications of a reallocation of savings among alternative uses within the eurozone that results from the ECB's policies, show that there is every reason to be concerned about the Target imbalances. The sort of asymmetric monetary expansion they represent has no counterpart in the US system. If the euro is to survive politically, a settlement mechanism must be introduced in the eurozone.

To be sure, the potential Target losses are a powerful reason why the Northern euro countries should fear a breakup of the euro, although they are certainly not the only reason for concern. However, Europe's continued existence cannot be based upon the fear of a breakup, but should instead be founded on the prospects of mutually beneficial cooperation. The eurozone must find its way back to a system of fair, voluntary exchange, and to budget constraints that reflect the true scarcity of resources. Copying the monetary rules of the US could be one way to achieve this goal.

\section{References}

Buiter, W. and E. Rahbari (2012a), "Looking into the Deep Pockets of the ECB”, Citi Economics, Global Economics View, 27 February.

Buiter, W. and E. Rahbari (2012b), "Target2 Redux: The Simple Accountancy and Slightly More Complex Economics of Bundesbank Loss Exposure through the Eurosystem", Citi Economics, Globa Economics, 16 October.

De Grauwe, P. and Y. Ji (2012), "How Germany Can Avoid Wealth Losses If the Eurozone Breaks Up: Limit Conversion to German Residents. What Germany Should Fear Most Is Its Own Fear", VoxEU.org, 18 September.

Homburg, St. (2012), "Der neue Kurs der europäischen Zentralbank", Wirtschaftsdienst 92(10), October.

Kohler, W. (2012), "The Eurosystem in Times of Crises: Greece in the Role of a Reserve Currency Country?", CESifo Forum 13, Special Issue, January, 14-22.

Neumann, M.J.M. (1998), "Geldwertstabilität: Bedrohung und Bewährung", in: Deutsche Bundesbank (ed.), 50 Jahre Deutsche Mark - Notenbank und Währung in Deutschland seit 1948, Munich.

Ruhkamp, S. (2012), "Die Bundesbank fordert von der EZB bessere Sicherheiten“, Frankfurter Allgemeine Zeitung, 1 March.

Sinn, H.-W. and H. Feist (1999), "Eurowinners and Eurolosers: The Distribution of Seignorage Wealth in EMU", European Journal of Political Economy 13, 1979, 665-689.

Sinn, H.-W. (2011a), "Die riskante Kreditersatzpolitik der EZB," Frankfurter Allgemeine Zeitung, 4 May (English translation: "The ECB's Stealth Bailout", VoxEU.org, 1 June)

Sinn, H.-W. (2011b), "On and off Target”, VoxEU.org, 14 June.

Sinn, H.-W. (2012a), "Fed versus ECB: How Target Debts Can be Repaid", VoxEU.org, 10 March.

Sinn, H.-W. (2012b), Die Target-Falle. Gefahren für unser Geld und unsere Kinder, Munich, Hanser.
Sinn, H.-W. and T. Wollmershäuser (2012), Target Loans, Current Account Balances and Capital Flows: The ECB's Rescue Facility, International Tax and Public Finance 19, 468-508.

Tornell, A. and F. Westermann (2012), "The tragedy of the Commons at the European Central Bank and the Next Rescue", VoxEu.org, 22 June.

Wenger, E. (1997), "Nicht 90, sondern 150 Milliarden Verlust durch den Euro", Frankfurter Allgemeine Zeitung, 21 July.

Whelan, K (2012), “TARGET2: Not Why Germans Should Fear a Euro Breakup", VoxEU.org, 29 April. 